\title{
Genetic analysis of somatic cell score and udder type traits in South African Holstein cows
}

\author{
B. Dube ${ }^{1}$, K. Dzama ${ }^{2 \#}$ and C.B. Banga ${ }^{3}$ \\ ${ }^{1}$ Department of Livestock \& Pasture Science, University of Fort Hare, Private Bag X1314, Alice 5700, South Africa \\ ${ }^{2}$ Department of Animal Sciences, Stellenbosch University, Private Bag X1, Matieland 7602, South Africa \\ ${ }^{3}$ ARC Livestock Business Division, Private Bag X2, Irene 0062, South Africa
}

\begin{abstract}
Selection accuracy for resistance to mastitis may be increased by combining somatic cell score (SCS) and udder type into an udder health index, using genetic parameter estimates among them. A multi-trait animal model was used to estimate genetic parameters among lactation average SCS and udder type traits in South African Holstein cattle, through REML procedures. Data comprised records on 22999 Holstein cows in 722 herds, collected through the National Milk Recording Scheme from 1996 to 2002. Average SCS in the first three lactations $\left(\mathrm{SCS}_{1}, \mathrm{SCS}_{2}, \mathrm{SCS}_{3}\right)$ were considered as different traits and the udder type traits were fore udder attachment (FUA), rear udder height (RUH), udder cleft (UC), udder depth (UD), fore teat length (FTL) and fore teat placement (FTP). Heritability estimates for SCS were $0.19 \pm 0.02,0.17 \pm 0.02$ and 0.19 \pm 0.02 , respectively for $\mathrm{SCS}_{1}, \mathrm{SCS}_{2}$ and $\mathrm{SCS}_{3}$. Udder type traits had heritability estimates ranging from 0.13 \pm 0.01 for UC to $0.34 \pm 0.01$ for FTL. The genetic correlations between lactation SCS ranged from 0.82 \pm 0.04 to $0.99 \pm 0.03$ for correlations of $\mathrm{SCS}_{3}$ with $\mathrm{SCS}_{1}$ and $\mathrm{SCS}_{2}$, respectively. Genetic correlations between SCS and udder type traits were in the range $-0.01 \pm 0.07$ between FUA and SCS $_{3}$ to $-0.38 \pm 0.04$ between UD and $\mathrm{SCS}_{1}$ and $\mathrm{SCS}_{2}$. Slow genetic progress is expected when selection is applied independently on SCS and udder type traits, due to the generally low heritability estimates. Low, shallow udders with narrowly placed teats are associated with low SCS in the South African Holstein population.
\end{abstract}

Keywords: Genetic parameters, mastitis, selection accuracy, udder health

\#Corresponding author. E-mail: Kdzama@sun.ac.za

\section{Introduction}

Resistance to mastitis is one of the most important traits affecting profitability in the dairy industry and its improvement is desirable for numerous reasons (Shook, 1989). Mastitis affects milk production and quality resulting in multiple economic losses (Colleau \& Le Bihan-Duval, 1995).

Improvement of udder health management has been accompanied by an increase in clinical mastitis cases caused by environmental bacteria in well-managed herds (Bramley, 1990; Gonzalez et al., 1990; DeGraves \& Fetrow, 1993). This may be due to developments in health care that allow immunologically inferior animals to reproduce (Dunklee et al., 1994). Although improvement of health standards is welcome, breeding principles that have long-lasting, cumulative and permanent effects should be developed and implemented.

Direct selection for resistance to mastitis is not widely practiced primarily because of its low heritability (Amin et al., 2002; Zwald et al., 2004; Koivula et al., 2005) and the fact that mastitis incidences are difficult to measure. Somatic cell count (SCC) has been considered as the most suitable indicator trait for mastitis resistance in view of its medium to high genetic correlation with and its higher heritability than mastitis (Mrode \& Swanson, 1996). Somatic cell count is also relatively easy and inexpensive to measure and is routinely recorded in most animal recording schemes, including in South Africa. The distribution of SCC is positively skewed and its variances among groups or herds are heterogeneous (Ali \& Shook, 1980); hence SCC is usually transformed logarithmically to somatic cell score (SCS).

The inclusion of udder conformation traits as indicator traits has been suggested as a means of improving accuracy of selection for resistance to mastitis (Rogers et al., 1991; De Jong \& Lansbergen, 1996; Gengler \& Groen, 1997; Mrode et al., 1998;). These traits are routinely measured in most animal breeding schemes. In addition, linear type traits are more heritable than mastitis incidence and SCS (Rupp \& Boichard, 1999; DeGroot et al., 2002; Marie-Etancelin et al., 2005). 
Selection in South African Holstein cattle has been mostly on milk yield, which has a deleterious effect on udder health (Castillo-Juarez et al., 2002; Hansen et al., 2002; Koivula et al., 2005). Serrano et al. (2003) pointed out that a fixation of alleles that diminish mastitis resistance occurs in breeds that have a long history of selection to improve milk yield. However, in South Africa, selection for milk yield may have changed the frequency of alleles that confer resistance to mastitis as a correlated response to selection on milk yield. Use of SCS to improve mastitis resistance as the only indicator trait results in low accuracy of selection which can be improved by incorporating other indicator traits such as udder type traits into the selection criteria. Genetic correlations between SCS and udder type traits are needed to properly evaluate the usefulness of selection on udder characteristics. This would help identify udder type traits that may help reduce the rate of increase of mastitis incidence associated with increase in milk yield.

The primary objective of this study was to estimate genetic parameters among SCS and udder type traits in order to enable more accurate selection for improved udder health in South African Holstein cattle.

\section{Materials and Methods}

Traits analysed were SCS for the first three lactations $\left(\mathrm{SCS}_{1}, \mathrm{SCS}_{2}\right.$ and $\left.\mathrm{SCS}_{3}\right)$ and udder type traits (fore udder attachment, rear udder height, udder cleft, udder depth, fore teat length and fore teat placement). Fore udder attachment (FUA) and udder cleft (UC) affect the extent to which the udder can be damaged and the ease with which it can be handled during milking. Rear udder height (RUH) and udder depth (UD) influence the risk of udder infection through contact with the ground. Fore teat placement (FTP) and fore teat length (FTL) affect the ease of machine-milking and milking speed, which may have an effect on risk of infection. Udder type traits were classified by 45 different classifiers on cows in their first lactation, on a linear biological scale of one to nine. These cows were aged between 17 and 39 months at calving and between 20 and 45 months at classification. Average age at calving was 28.46 months with a standard deviation of 4.12 months, while age at classification averaged 32.12 months with a 4.65 standard deviation. The biological extremes and illustrations of udder type traits are shown in Table 1 and Appendix I, respectively.

Table 1 Udder type traits, their abbreviations and scoring system

\begin{tabular}{llll}
\hline \multirow{2}{*}{ Traits } & \multirow{2}{*}{ Abbreviation } & \multicolumn{2}{c}{ Biological extremes } \\
\cline { 3 - 4 } & & & 9 \\
Fore udder attachment & FUA & Loosely attached & Tightly attached \\
Rear udder height & RUH & Very low & Very high \\
Udder cleft & UC & Absent & Deep \\
Udder depth & UD & Below hock & Under-developed \\
Fore teat placement & FTP & External & Internal \\
Fore teat length & FTL & Very short & Very long \\
\end{tabular}

The original data set, comprising test day records for the first three lactations, was edited to remove animals with missing birthdates, calving dates and sires. As SCC has a highly skewed distribution and its variances among populations and groups are heterogeneous, somatic cell score (SCS) was defined by a logarithmic transformation $\left(\log _{10}\right.$ SCC) of SCC (Ali \& Shook, 1980). Average SCS for each lactation was calculated and cows with less than four test-day SCS records per lactation were removed. Further edits were done to remove: i) test-day milk yield less than $2.5 \mathrm{~kg}$ and greater than $90 \mathrm{~kg}$; ii) days in milk less than 150 and greater than 305 for SCS, and iii) days in milk less than 5 and greater than 300 for udder type traits at classification. Lactations less than 150 days and greater than 305 days were also not included as they are considered not to represent 'official lactations' under the standards of the South African National Improvement Scheme (Mostert et al., 2006a).

Two seasons of calving were defined as summer (October - March) and winter (April - September). Although information on lactation number was available, a restriction was imposed on age at calving to 
exclude cows with wrong lactation numbers. The restriction was that cows in first, second and third lactations were 20 - 42, 30 - 54 and 40 - 66 months of age, respectively (Mostert et al., 2004; 2006a). Testday data were merged with udder type data.

Contemporary groups for SCS were created by the concatenation of herd, year and season of calving. The udder type traits contemporary groups were created by concatenating herd, year and season of classification and classifier. Each contemporary group had at least five cows and two sires. Cows without a first lactation SCS record were removed to take into account the selection of cows which made subsequent records and to avoid selection bias. The final data set analysed is shown in Table 2.

Table 2 Structure of the data set of the Holstein cows

\begin{tabular}{lcccc}
\hline Traits & No of records & No of sires & No of herds & Contemporary groups \\
\hline $\mathrm{SCS}_{1}$ & 22999 & 1501 & 722 & 3833 \\
$\mathrm{SCS}_{2}$ & 11722 & 670 & 254 & 2512 \\
$\mathrm{SCS}_{3}$ & 5276 & 268 & 89 & 1428 \\
Udder type traits & 10781 & 758 & 270 & 2222 \\
\hline
\end{tabular}

$\mathrm{SCS}_{1}, \mathrm{SCS}_{2}$ and $\mathrm{SCS}_{3}-$ somatic cell score for first, second and third lactations, respectively.

The Variance Component Estimation-Restricted Maximum Likelihood (VCE-REML) Version 5 programme of Kovac \& Groeneveld (2003) was used in the (co)variance component estimation for lactation SCS and udder type traits. A nine-trait analysis for SCS for the three lactations and the six udder type traits was conducted. The fixed effects included in the estimation for SCS and udder type traits are shown in Table 3.

Table 3 Effects included in (co)variance component estimation in Holstein cows

\begin{tabular}{lcccccccc}
\hline Trait & HYSC & HYS & AGE & AGEPP $^{2}$ & AGEC & AGEC $^{2}$ & DIM & DIM $^{2}$ \\
\hline SCS $_{1}$ & & $\mathrm{X}$ & $\mathrm{X}$ & & & & $\mathrm{X}$ & $\mathrm{X}$ \\
SCS $_{2}$ & & $\mathrm{X}$ & $\mathrm{X}$ & $\mathrm{X}$ & & & $\mathrm{X}$ & \\
SCS $_{3}$ & & $\mathrm{X}$ & $\mathrm{X}$ & $\mathrm{X}$ & & & $\mathrm{X}$ & \\
FUA & $\mathrm{X}$ & & $\mathrm{X}$ & $\mathrm{X}$ & & & & \\
RUH & $\mathrm{X}$ & & & & & & $\mathrm{X}$ & $\mathrm{X}$ \\
UC & $\mathrm{X}$ & & $\mathrm{X}$ & $\mathrm{X}$ & & & $\mathrm{X}$ & $\mathrm{X}$ \\
UD & $\mathrm{X}$ & & $\mathrm{X}$ & $\mathrm{X}$ & $\mathrm{X}$ & $\mathrm{X}$ & $\mathrm{X}$ & $\mathrm{X}$ \\
FTP & $\mathrm{X}$ & & $\mathrm{X}$ & $\mathrm{X}$ & $\mathrm{X}$ & $\mathrm{X}$ & $\mathrm{X}$ & $\mathrm{X}$ \\
FTL & $\mathrm{X}$ & & $\mathrm{X}$ & & & & &
\end{tabular}

X - indicates factor included; HYSC - herd, year, season of classification, classifier; HYS - herd, year and season of calving; AGE - age at calving; AGEPP $^{2}$ - age at calving squared; AGEC - age at classification; AGEC ${ }^{2}-$ age at $^{2}$ classification squared; DIM - lactation length; $\mathrm{DIM}^{2}$ - lactation length squared; $\mathrm{SCS}_{1}, \mathrm{SCS}_{2}$ and $\mathrm{SCS}_{3}-$ somatic cell score for first, second and third lactations, respectively; FUA - fore udder attachment; RUH - rear udder height; UC - udder cleft; UD - udder depth; FTP - fore teat placement; FTL - fore teat length.

The mixed model equation used for the analyses is given below.

$$
y=X b+Z u+e
$$

The expectations and covariance structures for the multi-trait analysis are as follows: 
$E\left[\begin{array}{c}y_{i} \\ y_{j} \\ u_{i} \\ u_{j} \\ e_{i} \\ e_{j}\end{array}\right]=\left[\begin{array}{c}X_{i} b_{i} \\ X_{j} b_{j} \\ 0 \\ 0 \\ 0 \\ 0\end{array}\right] \quad V\left[\begin{array}{c}u_{i} \\ u_{j} \\ e_{i} \\ e_{j}\end{array}\right]=\left[\begin{array}{cccc}A \sigma_{u i}^{2} & A \sigma_{u i j} & 0 & 0 \\ & A \sigma_{u j}^{2} & 0 & 0 \\ & & I \sigma_{e i}^{2} & I \sigma_{e i j} \\ & & & I \sigma_{e j}^{2}\end{array}\right] \quad V\left[\begin{array}{l}y_{i} \\ y_{j}\end{array}\right]=\left[\begin{array}{c}Z_{i} A Z_{i}^{\prime} \sigma_{u i}^{2}+I \sigma_{e i}^{2} \\ Z_{j} A Z_{j}^{\prime} \sigma_{u j}^{2}+I \sigma_{e j}^{2}\end{array}\right]$

$i \neq j, i j=j i$

where, $y$ is the vector of observations, $X$ is the incidence matrix relating the vector of fixed effects $b$ to $y, Z$ is the incidence matrix relating the vector of random animal additive genetic effects $u$ to $y$ and $e$ is the vector of random residuals, $A$ is the numerator relationship matrix, $I$ is an identity matrix, $\sigma_{u}^{2}$ is the genetic variance, $\sigma_{e}^{2}$ is the residual variance, $\sigma_{u i j}$ and $\sigma_{e i j}$ are respectively, the genetic and residual covariances between traits $i$ and $j$.

Genetic trends of SCS for each breed were determined by estimating breeding values for each trait and plotting average estimated breeding value by year of birth.

\section{Results}

The structure of the data set and descriptive statistics of traits for the Holstein used in the (co)variance component estimation are shown in Tables 4. Somatic cell score had highest (5.20) and lowest (4.47) scores in third and first lactation, respectively. These averages are typical of South African herds, which generally have higher SCS levels than those in other countries with well developed dairy industries. Nearly half of the animals did not have udder type scores. The highest udder type score was 4.46 for fore teat placement, while the lowest was 6.39 for udder cleft.

Table 4 Summary statistics for Holstein cows

\begin{tabular}{lcccc}
\hline Trait & No of records & Mean & $\begin{array}{c}\text { Standard } \\
\text { Deviation }\end{array}$ & $\begin{array}{c}\text { Coefficient } \\
\text { of Variation }\end{array}$ \\
\hline SCS $_{1}$ & 22999 & 4.47 & 0.81 & 18 \\
SCS $_{2}$ & 11722 & 4.89 & 0.91 & 19 \\
SCS & 5276 & 5.20 & 0.96 & 18 \\
FUA & 10781 & 6.16 & 1.28 & 21 \\
RUH & 10781 & 6.22 & 1.00 & 16 \\
UC & 10781 & 6.39 & 1.28 & 20 \\
UD & 10781 & 5.19 & 1.06 & 20 \\
FTP & 10781 & 4.53 & 0.90 & 20 \\
FTL & 10781 & 4.52 & 1.19 & 26
\end{tabular}

$\mathrm{SCS}_{1}, \mathrm{SCS}_{2}$ and $\mathrm{SCS}_{3}-$ somatic cell score for first, second and third lactations, respectively; FUA - fore udder attachment; RUH - rear udder height; UC - udder cleft; UD - udder depth; FTP - fore teat placement; FTL - fore teat length.

Heritability estimates for SCS in the first three lactations, shown in Table 5, were in the range 0.17 \pm 0.02 for $\mathrm{SCS}_{2}$ to $0.19 \pm 0.02$ for $\mathrm{SCS}_{1}$ and $\mathrm{SCS}_{3}$. Estimates for udder type traits ranged from $0.13 \pm 0.01$ for udder cleft to $0.34 \pm 0.01$ for fore teat length. These are shown Table 6 .

The genetic correlations among lactational SCS were all generally high and are shown in Table 5 . Correlations were higher between adjacent lactations and decreased as the distance between lactations 
increased. The lowest correlation $(0.82 \pm 0.04)$ was between lactations one and three, while the highest genetic correlation of $0.99 \pm 0.03$ was between second and third lactational SCS.

Table 5 Heritability estimates of (diagonal) and genetic correlations (off-diagonal) among lactation somatic cell scores in Holstein cows

\begin{tabular}{llll}
\hline & $\mathrm{SCS}_{1}$ & $\mathrm{SCS}_{2}$ & $\mathrm{SCS}_{3}$ \\
\hline $\mathrm{SCS}_{1}$ & $0.19 \pm 0.02$ & $0.88 \pm 0.03$ & $0.82 \pm 0.04$ \\
$\mathrm{SCS}_{2}$ & & $0.17 \pm 0.02$ & $0.99 \pm 0.03$ \\
$\mathrm{SCS}_{3}$ & & & $0.19 \pm 0.02$
\end{tabular}

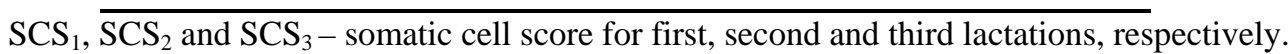

Table 6 Heritability estimates of (diagonal) and genetic correlations (off-diagonal) among udder type traits in Holstein cows

\begin{tabular}{lccccrr}
\hline & FUA & RUH & UC & UD & FTP & \multicolumn{1}{c}{ FTL } \\
\hline FUA & $0.16 \pm 0.01$ & $0.46 \pm 0.02$ & $0.64 \pm 0.03$ & $0.71 \pm 0.02$ & $0.45 \pm 0.03$ & $-0.08 \pm 0.02$ \\
RUH & & $0.18 \pm 0.02$ & $0.72 \pm 0.03$ & $0.35 \pm 0.03$ & $0.38 \pm 0.03$ & $-0.08 \pm 0.03$ \\
UC & & & $0.13 \pm 0.01$ & $0.48 \pm 0.05$ & $0.58 \pm 0.04$ & $-0.002 \pm 0.01$ \\
UD & & & & $0.17 \pm 0.01$ & $0.45 \pm 0.03$ & $0.06 \pm 0.02$ \\
FTP & & & & & $0.20 \pm 0.02$ & $-0.23 \pm 0.01$ \\
FTL & & & & & & $0.34 \pm 0.01$ \\
\hline
\end{tabular}

FUA - fore udder attachment; RUH - rear udder height; UC - udder cleft; UD - udder depth; FTP - fore teat placement; FTL - fore teat length.

Table 7 Genetic correlations between udder type traits and SCS

\begin{tabular}{llll}
\hline & SCS $_{1}$ & SCS $_{2}$ & SCS $_{3}$ \\
\hline FUA & $-0.09 \pm 0.04$ & $03 \pm 0.04$ & $01 \pm 0.07$ \\
RUH & $0.11 \pm 0.04$ & $25 \pm 0.04$ & $10 \pm 0.09$ \\
UC & $0.16 \pm 0.05$ & $19 \pm 0.04$ & $02 \pm 0.10$ \\
UD & $-0.38 \pm 0.04$ & $38 \pm 0.04$ & $36 \pm 0.05$ \\
FTP & $-0.27 \pm 0.03$ & $21 \pm 0.03$ & $26 \pm 0.06$ \\
FTL & $0.27 \pm 0.03$ & $10 \pm 0.02$ & $10 \pm 0.03$ \\
\hline
\end{tabular}

$\mathrm{SCS}_{1}, \mathrm{SCS}_{2}$ and $\mathrm{SCS}_{3}-$ somatic cell score for first, second and third lactations, respectively; FUA - fore udder attachment; RUH - rear udder height; UC - udder cleft; UD - udder depth; FTP - fore teat placement; FTL - fore teat length.

The genetic correlations among udder type traits are shown in Table 6. Udder cleft and rear udder height had the highest correlation of $0.72 \pm 0.03$. Fore teat length had the lowest correlations with other udder type traits, ranging from very low $(-0.002 \pm 0.01)$ to $-0.23 \pm 0.01$ with udder cleft and fore teat placement, respectively. 
The genetic correlations between udder type traits and SCS for the three lactations are shown in Table 7. Correlations ranged from $-0.01 \pm 0.07$ between fore udder attachment and SCS in third lactation, to $-0.38 \pm 0.04$ between udder depth and SCS in second and third lactation.

Figure 1 shows genetic trends for lactation SCS and the phenotypic trend for average SCS across lactations in Holstein cows. The estimated breeding values (EBV) for lactation SCS increased from 1988 to 1999 at an average rate of 0.01 SCS per year. During the same period, the phenotypic trend decreased at an average rate of 0.11 SCS per year.

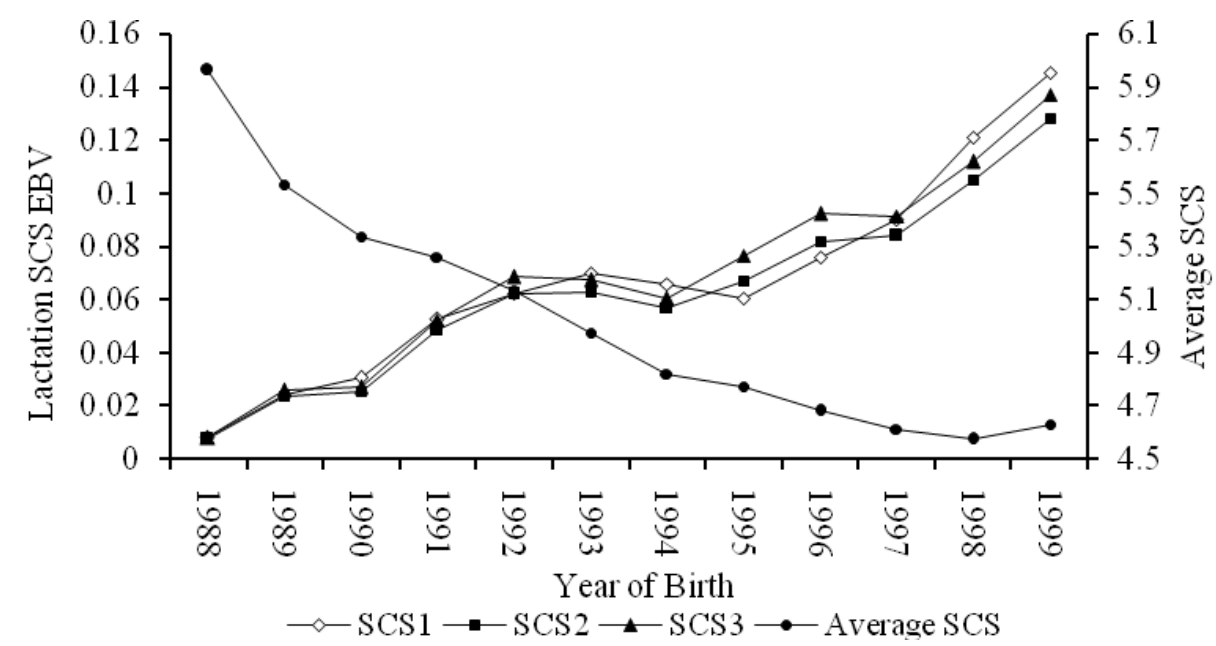

Figure 1 Genetic trends for lactation somatic cell score and phenotypic trend for across lactations average somatic cell score in Holstein cows.

(EBV - estimated breeding value; SCS1, SCS2 and SCS3 - somatic cell score in first, second and third lactations, respectively).

The genetic trends for udder type traits are shown in Figures 2.1 to 2.6. Average estimated breeding values for all udder type traits were relatively constant from 1985 to 1991 after which they increased gradually until 1999. An exception was for fore teat length which decreased from 1985 to 1996 and then increased until 1999.

The genetic trends for udder type traits are shown in Figures 2.1 to 2.6. Average estimated breeding values for all udder type traits were relatively constant from 1985 to 1991 after which they increased gradually until 1999. An exception was for fore teat length which decreased from 1985 to 1996 and then increased until 1999.

\section{Discussion}

The results of this study reflect the generally low heritability of SCS, in agreement with other studies (Poso \& Mantysaari, 1996; Boettcher et al., 1998). In general, the results are similar to those obtained using SCS averages but higher than those from individual test-day models. The low heritability of SCS will result in slow response to selection for resistance to mastitis. This will be further slowed down by the less than perfect genetic correlation between SCS and mastitis (Koivula et al., 2005), when SCS is used as the only indicator trait. Including udder type traits in the selection criterion may help increase its accuracy of selection.

The correlations were similar to those reported by Reents et al. (1995), Boettcher et al. (1998), Carlen et al. (2004) and Mostert et al. (2004). However, Poso \& Mantysaari (1996) and Mrode \& Swanson (2003) obtained lower correlations for lactation one with lactations two and three. Higher correlations observed between adjacent lactations may be due to adjacent lactations being under the control of more common genes. Somatic cell scores in second and third lactations can be considered as repeated measures of the same trait. 


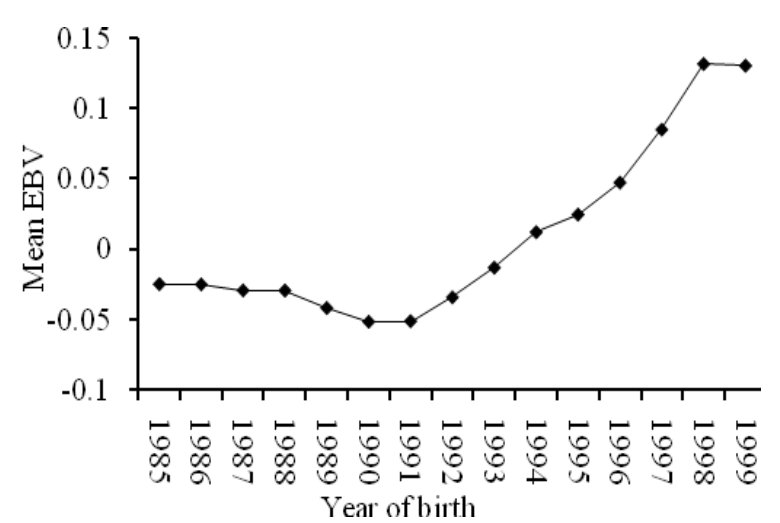

a) Fore udder attachment

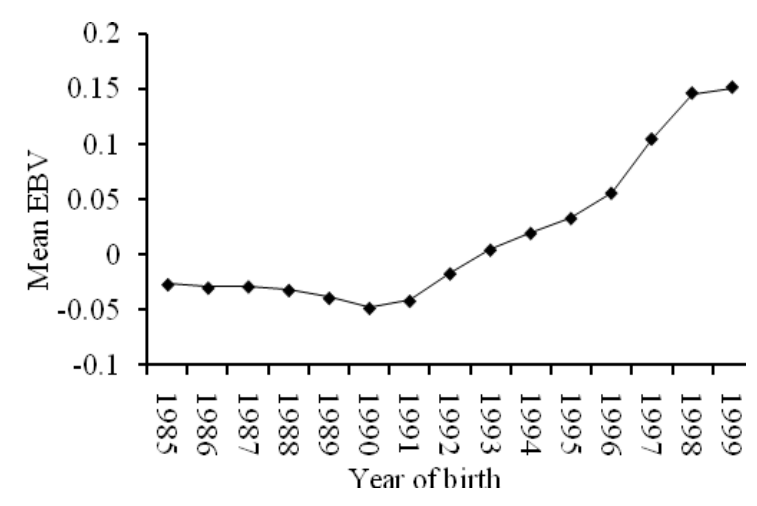

c) Udder cleft

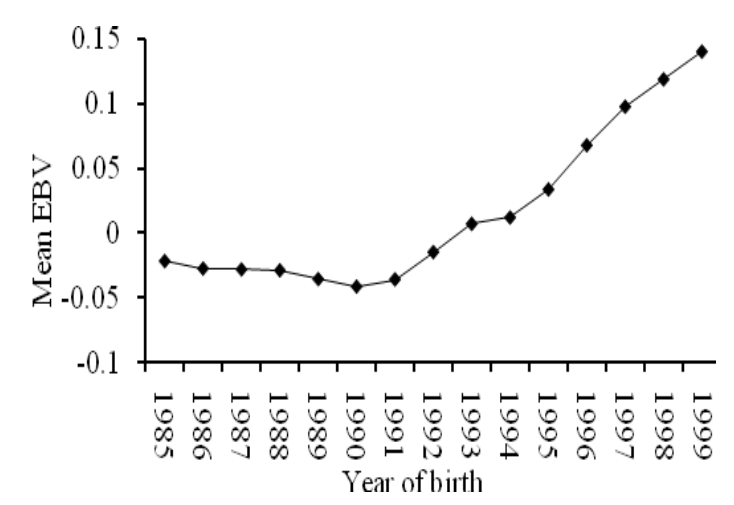

e) Fore teat placement

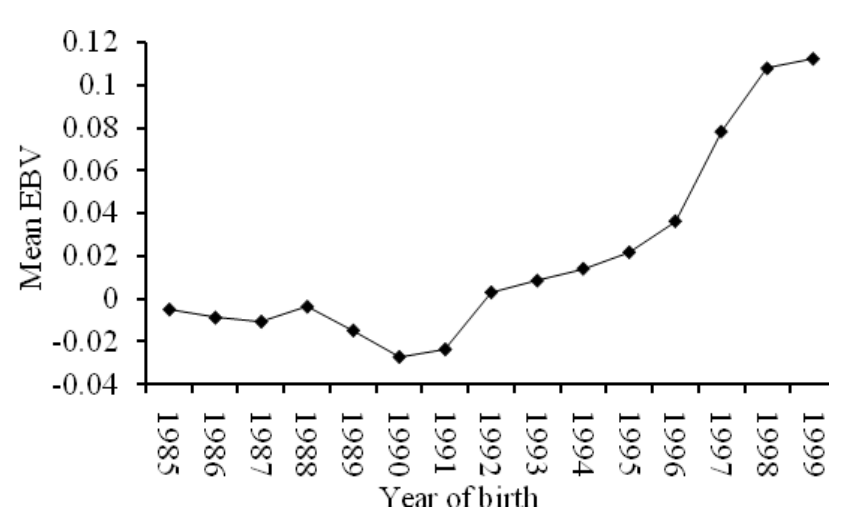

b) Rear udder height

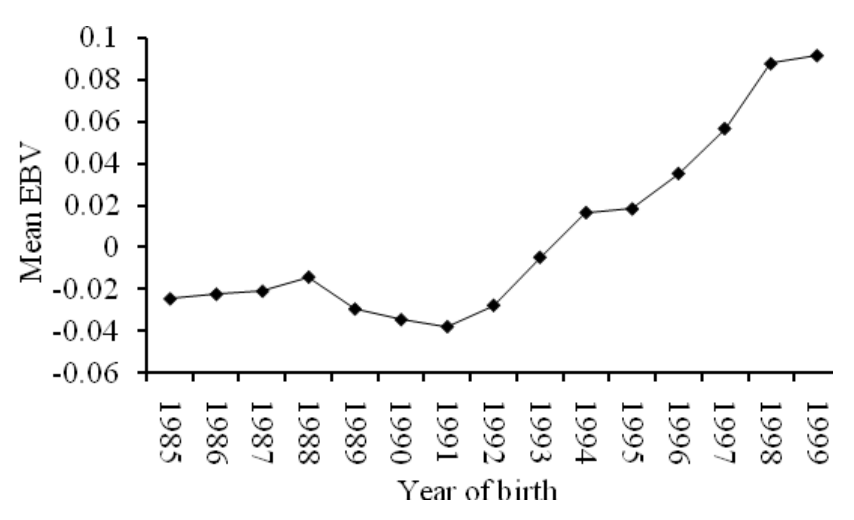

d) Udder depth

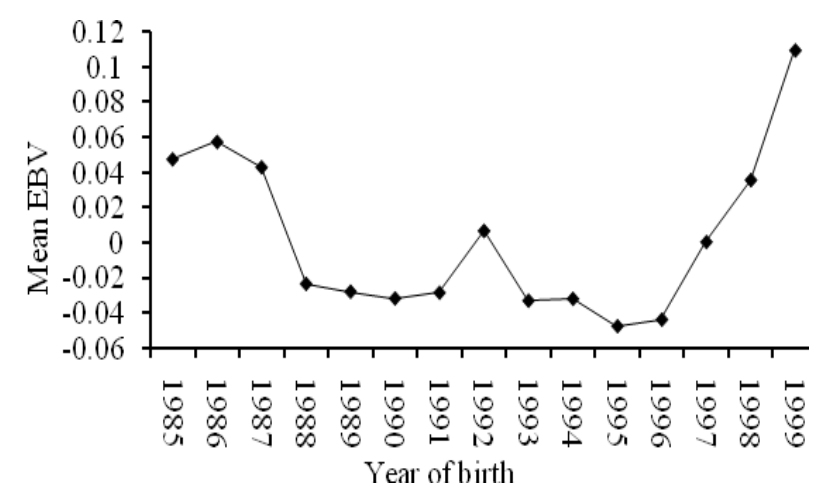

f) Fore teat length

Figure 2 Genetic trends for udder type traits in Holstein cows. (EBV - estimated breeding value).

The heritability estimates of udder type traits obtained in this study compared well with those obtained recently in the same population (Setati et al., 2004; Theron \& Mostert, 2004) as well as in several other studies (Weigel et al., 1997; Boettcher et al., 1998; Fuerst-Waltl et al., 1998). Perez-Cabal \& Alenda (2002) obtained much lower correlations for udder cleft, fore teat length and fore udder attachment. Udder type traits exhibit low to moderate heritability in South African Holstein cattle. This implies that slight genetic change may be achieved when selection is applied on these traits, which may help improve mastitis resistance. 
Most of the genetic correlations among udder type traits compared favourably with those of Boettcher et al. (1998). Correlations were generally higher than those reported in most previous studies (Harris et al., 1992; Rogers, 1996; Sorensen et al., 2000). The variation in these correlations shows differences in the interaction of genes coding for the different traits and differences in selection pressures applied. Traits that had high correlations were: i) fore udder attachment and udder depth; ii) fore udder attachment and udder cleft, and iii) rear udder height and udder cleft. Selection on one trait is expected to result in genetic change in another with which it is highly correlated. Thus, the number of traits in the selection criteria for mastitis resistance can be optimized, using these correlations, to achieve maximum genetic progress.

Genetic correlations between SCS and udder type traits from the current study were generally higher than those reported recently for the South African Jersey population (Banga \& Mostert, 2004) and most other literature estimates (Rogers et al., 1991; Zhang et al., 1994; Boettcher et al., 1998). Estimates were, however, within the range of those obtained by Rogers (1996), Rupp \& Boichard (1999) and DeGroot et al. (2002).

The results suggest that deep, loosely attached udders are associated with high SCS. This may be due to the fact that deeper udders are more prone to injury due to their relative position. Narrowly placed front teats are associated with low somatic cells, probably because of easy handling during machine-milking. The correlation between teat length and SCS is similar to that obtained by Rogers et al. (1991), who suggested that longer teats are prone to injury due to housing, handling and milking machine incompatibility.

The increase in genetic trends for SCS indicates a deterioration in resistance to mastitis. These trends may be a correlated response to intense selection for increased milk yield, which has remarkably increased genetic merit for milk yield in the past two decades (Mostert et al., 2004; Mostert et al., 2006b). Intense selection for milk yield causes an unfavourable response in udder health (Castillo-Juarez et al., 2002; Hansen et al., 2002; Koivula et al., 2005). Furthermore, the direction of selection of rear udder height and udder cleft may have resulted in increased SCS. This is supported by the increase in the scores of these udder type traits. Their correlations with SCS may be low to moderate, but their long term effect might have been notable.

The decrease in milk SCC may be attributable to improved udder health management. Such improvements in management are, however, not sustainable if they are counteracted by a deterioration in genetic merit, shown by the increasing genetic trend of SCS. These improvements allow immunologically inferior animals to reproduce (Dunklee et al., 1994). South African Holstein Breeders and producers are, however, not aware of the deterioration in udder health at genetic level as this has not been demonstrated in any previous study.

The genetic trends of udder type traits are similar to those obtained by Theron \& Mostert (2004) on the same breed. During the period after 1992 Holstein cows progressively had more tightly attached, higher, shallower udders with more pronounced udder clefts. Front teats were progressively becoming more narrowly placed. Teat lengths were reduced until probably when the breeders realized that they were becoming too short, then after 1995 teat lengths became longer.

The trends of some traits may have resulted from selection for higher milk production. Harris et al. (1992) pointed out that selection to improve milk production is likely to increase udder dimension and weaken fore udder attachment and depth. Genetic trends for udder type traits followed clearly discernible trends over the years, showing how responsive they are to selection. This suggests that changes can be expected if selection is carried out on some of these traits, which may also bring about correlated improvement in susceptibility to mastitis.

\section{Conclusions}

Genetic parameters obtained in this study form the basis for combining SCS and udder type traits to calculate genetic predictions for resistance to mastitis, using an udder health index, in South African Holstein cattle. Further research needs to be carried out to determine which traits may be included in such an index and the relative emphasis of each trait in the index. The improving phenotypic trend for SCS, despite a deterioration in genetic merit for resistance to mastitis, underscores the need to genetically improve udder health in South African Holstein cattle. 


\section{References}

Ali, A.K.A. \& Shook, G.E., 1980. An optimum transformation for somatic cell concentration in milk. J. Dairy Sci. 63, 487-490.

Amin, A.A., Gere, T. \& Kishk, W.H., 2002. Genetic and environmental relationship among udder conformation traits and mastitis incidence in Holstein-Friesian in two different environments. Arch. Tierz., Dummerstorf 45 (1), 129-138.

Banga, C.B. \& Mostert, B.E., 2004. Genetic correlations among somatic cell score and linear type traits in South African Jersey cattle. Proc. II Joint Congr. Grassl. Soc. Sthn Afr. and S. Afr. Soc. Anim. Sci., Cape Town, South Africa. pp. 122.

Boettcher, P.J., Dekkers, J.C.M. \& Kolstad, B.W., 1998. Development of an udder health index for sire selection based on somatic cell score, udder conformation and milking speed. J. Dairy Sci. 81, 1157-1168.

Bramley, A., 1990. Environmental mastitis. In: Am. Assoc. Bovine Pract. Natl. Mastitis Counc. Mtg. Proc., Indianapolis, IN. Natl. Mastitis Counc., Inc., Arlington, VA. pp. 158-170.

Carlen, E., Strandberg, E. \& Roth, A., 2004. Genetic parameters for clinical mastitis, somatic cell score and production in the first three lactations of Swedish Holstein cows. J. Dairy Sci. 87, 3062-3070.

Castillo-Juarez, H., Oltenacu, P.A. \& Cienfuegos-Rivas, E.G., 2002. Genetic and phenotypic relationships among milk production and composition traits in primiparous Holstein cows in two different herd environments. Livest. Prod. Sci. 78, 223-231.

Colleau, J.J. \& Le Bihan-Duval, E., 1995. A simulation study of selection methods to improve mastitis resistance in dairy cattle. J. Dairy Sci. 78, 659-671.

DeGraves, F.J. \& Fetrow, J., 1993. Economics of mastitis and mastitis control. Vet. Clin. North Am. Food Anim. Pract. 9, 421-434.

DeGroot, B.J., Keown, J.F., Van Vleck, L.D. \& Marotz, E.L., 2002. Genetic parameters and responses of linear type, yield traits and somatic cell scores to divergent selection for predicted transmitting ability for type in Holsteins. J. Dairy Sci. 85, 1578-1585.

De Jong, G. \& Lansbergen, L., 1996. Udder health index: selection for mastitis resistance. In: Proc. Int. Workshop Genet. Improvement of Functional Traits in Cattle. Bull. No. 12. Int. Committee Anim. Recording, Uppsala, Sweden. pp. 42-47.

Dunklee, J.S., Freeman, A.E. \& Kelley, D.H., 1994. Comparison of Holsteins selected for high and average milk production. 2. Health and reproductive response to selection for milk. J. Dairy Sci. 77, 3683-3690.

Fuerst-Waltl, B., Solkner, J., Essl, A., Hoeschele, I. \& Fuerst, C., 1998. Non-linearity in the genetic relationship between milk yield and type traits in Holstein cattle. Livest. Prod. Sci. 57, 41-47.

Gengler, N. \& Groen, A.F., 1997. Potential benefits from multitrait evaluation - an example in selection for mastitis resistance based on somatic cell score and udder conformation. A simulation study. Interbull 15. pp. 106-112.

Gonzalez, R.N., Jasper, D.E., Kronlund, N.C., Farver, T.B., Cullor, J.S., Bushnell, R.B. \& Dellinger, J.D., 1990. Clinical mastitis in two California dairy herds participating in contagious mastitis control programs. J. Dairy Sci. 73, 648-660.

Hansen, M., Lund, M.S., Sorensen, M.K. \& Christensen, L.G., 2002. Genetic parameters of dairy character, protein yield, clinical mastitis, and other diseases in the Danish Holstein cattle. J. Dairy Sci. 85, 445-452.

Harris, B.L., Freeman, A.E. \& Metzger, E., 1992. Genetic and phenotypic parameters for type and production in Guernsey dairy cows. J. Dairy Sci. 75, 1147-1153.

Koivula, M., Mantysaari, E.A., Negussie, E. \& Serenius, T., 2005. Genetic and phenotypic relationships among milk yield and somatic cell count before and after mastitis. J. Dairy Sci. 88, 827-833.

Kovac, M. \& Groeneveld, E., 2003. VCE-5 User's Guide and Reference Manual Version 5.1. Neustadt, Germany.

Marie-Etancelin, C., Astruc, J.M., Porte, D., Larroque, H. \& Robert-Granie, C., 2005. Multiple-trait genetic parameters and genetic evaluation of udder-type traits in Lacaune ewes. Livest. Prod. Sci. 97, 211-218. 
Mostert, B.E., Banga, C.B., Groeneveld, E. \& Kanfer, F.H.J., 2004. Breeding value estimation for somatic cell score in South African dairy cattle. S. Afr. J. Anim. Sci. 34 (Suppl. 2), 32-34.

Mostert, B.E., Theron, H.E., Kanfer, F.H.J. \& Van Marle-Köster, E., 2006a. Comparison of breeding values and genetic trends for production traits estimated by a lactation model and a fixed regression test-day model. S. Afr. J. Anim. Sci. 36, 71-78.

Mostert, B.E., Theron, H.E., Kanfer, F.H.J. \& Van Marle-Köster, E., 2006b. Test-day models for South African cattle for participation in international evaluations. S. Afr. J. Anim. Sci. 36, 58-70.

Mrode, R.A. \& Swanson, G.J.T., 1996. Genetic and statistical properties of somatic cell count and its suitability as an indirect means of reducing the incidence of mastitis in dairy cattle. Anim. Breed. Abstr. 64, 847-857.

Mrode, R.A. \& Swanson, G.J.T., 2003. Estimation of genetic parameters for somatic cell count in the first three lactations using random regression. Livest. Prod. Sci. 79, 239-247.

Mrode, R.A., Swanson, G.J.T. \& Winters, M.S., 1998. Genetic parameters and evaluations for somatic cell counts and its relationship with production and type traits in some dairy breeds in the United Kingdom. Anim. Sci. 66, 569-576.

Perez-Cabal, M.A. \& Alenda, R., 2002. Genetic relationships between lifetime profit and type traits in Spanish Holstein cows. J. Dairy Sci. 85, 3480-3491.

Poso, J. \& Mantysaari, E., 1996. Relationships between clinical mastitis, somatic cell score, and production for the first three lactations of Finnish Ayshire. J. Dairy Sci. 79, 1284-1291.

Reents, F., Jamrozik, J., Schaeffer, L.R. \& Dekkers, J.C.M., 1995. Estimation of genetic parameters for test day records of somatic cell score. J. Dairy Sci. 78, 2847-2857.

Rogers, G.W., 1996. Using type for improving health of the udder and feet and legs. Proc Int. Workshop Genet. Improvement Functional Traits Cattle. Interbull 12. Int. Bull. Eval. Serv, Upsala, Sweden. pp. 33-41.

Rogers, G.W., Hargrove, G.L., Lawlor Jr, T.J. \& Ebersole, J.L., 1991. Correlations among linear type traits and somatic cell counts. J. Dairy Sci.74, 1087-1091.

Rupp, R. \& Boichard, D., 1999. Genetic parameters for clinical mastitis, somatic cell score, production, udder type traits and milking ease in first lactation Holsteins. J. Dairy Sci. 82, 2198-2204.

Serrano, M., Perez-Guzman, M.D., Montoro, V. \& Jurdo, J.J., 2003. Genetic analysis of somatic cell count and milk traits in Manchega ewes mean lactation and test-day approaches. Livest. Prod. Sci. 84, 1-10.

Setati, M.M., Norris, D., Banga, C.B. \& Benyi, K., 2004. Relationships between longevity and linear type traits in Holstein cattle of Southern Africa. Trop. Anim. Health Prod. 36, 807-814.

Shook, G.E., 1989. Selection for disease resistance. J. Dairy Sci. 72, 1348-1353.

Sorensen, M.K., Jensen, J. \& Christensen, L.G., 2000. Udder conformation and mastitis resistance in Danish first lactation cows: Heritabilities, genetic and environmental correlations. Acta Agric. Scand., Sect. A, Anim. Sci. 50, 72-82.

Theron, H.E. \& Mostert, B.E., 2004. Genetic analyses for conformation traits in South African Jersey and Holstein cattle. S. Afr. J. Anim. Sci. 34 (Suppl. 2), 47-49.

Weigel, D.J., Cassell, B.G. \& Pearson, R.E., 1997. Prediction of transmitting abilities for productive life and lifetime profitability from production, somatic cell count and type traits in milk markets for fluid milk and cheese. J. Dairy Sci. 80, 1398-1405.

World Holstein Friesian Federation, 2005. International Type Evaluation of Dairy Cattle. http://www.whff.info/index.php?content=typetraits_eval\&

Zhang, W.C., Dekkers, J.C.M., Banos, G. \& Burnside, E.B., 1994. Adjustment factors and genetic evaluation of somatic cell score and relationships with other traits of Canadian Holsteins. J. Dairy Sci. 77, 659-665.

Zwald, N.R., Weigel, K.A., Chang, Y.M., Welper, R.D. \& Clay, J.S., 2004. Genetic selection for health traits using producer-recorded recorded data. I. Incidence rates, heritability estimates and sire breeding values. J. Dairy Sci. 87, 4287-4294. 
Appendix I Illustrations of udder type traits (Source: World Holstein Friesian Federation, 2005)

a) Fore udder attachment

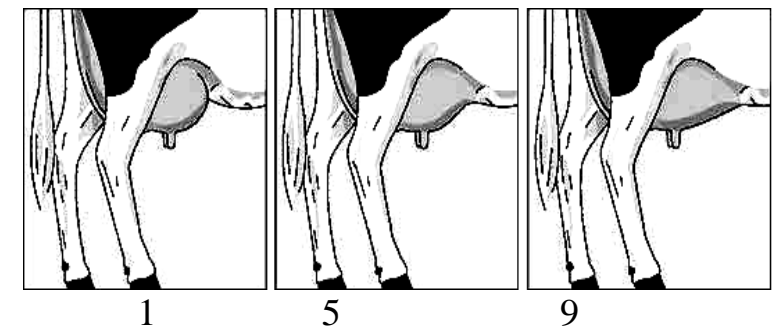

$1-3$ Weak and loose

4 - 7 Intermediate acceptable

8-9 Extremely strong and tight

\section{c) Rear udder height}

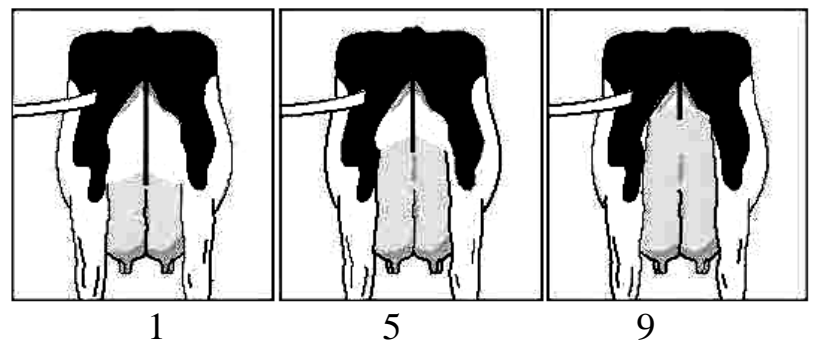

$1-3$ Very low

4-6 Intermediate

7 - 9 High

e) Fore teat placement

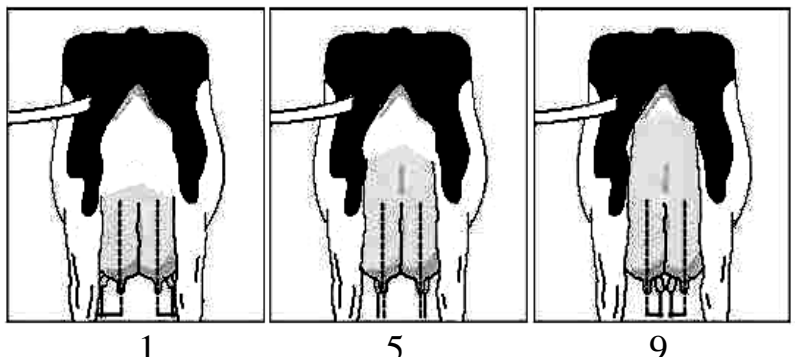

1 - 2 Outside of quarter

4 Midpoint

7 - 9 Inside of quarter b) Udder depth

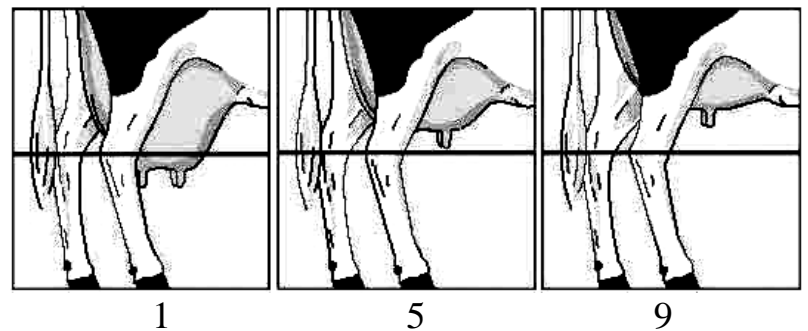

1) Below hock; 2) Level with hock; 5) Intermediate 9) Shallow and under-developed

d) Udder cleft

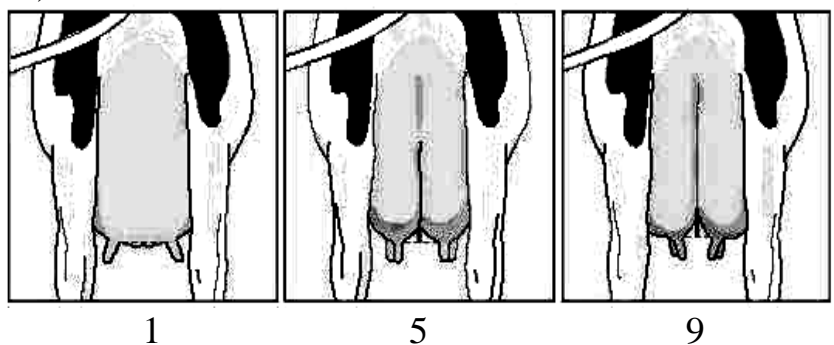

1) Convex to flat floor $(+1 \mathrm{~cm})$; 2) $+0.5 \mathrm{~cm}$; 3$) 0 \mathrm{~cm}$;

4) Slight definition $(-1 \mathrm{~cm}) ; 5)-2 \mathrm{~cm} ; 6)-3 \mathrm{~cm}$;

7) Deep definition (-4 cm); 8) $-5 \mathrm{~cm}$; 9) $-6 \mathrm{~cm}$

f) Fore teat length

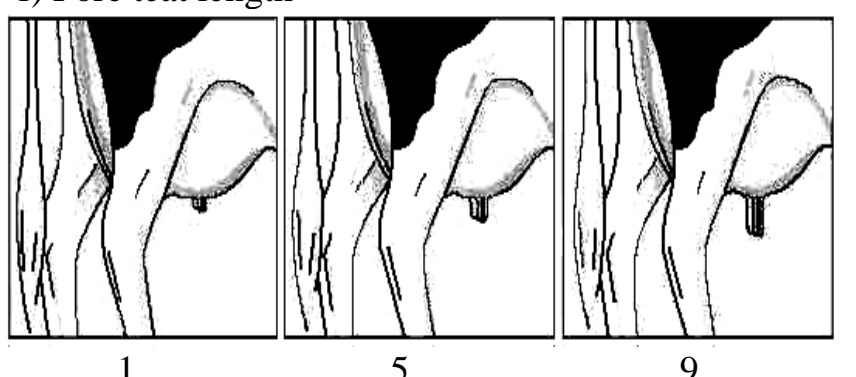

1

5

9

1 Short

4-6 Intermediate

7 -9 Long 